\title{
A comparative study between active and expectant management of premature rupture of membranes at term on fetomaternal and perinatal outcome in rural population
}

\author{
Rajani Rawat, Pragati Divedi*, Sukla Debbarma, Soniya Vishwakarma, Nupur Mittal
}

Department of Obstetrics and Gynecology, UPUMS, Saifai, Etawah, Uttar Pradesh, India

Received: 02 April 2018

Accepted: 30 April 2018

*Correspondence:

Dr. Pragati Divedi,

E-mail: drpragati_divedi@yahoo.com

Copyright: () the author(s), publisher and licensee Medip Academy. This is an open-access article distributed under the terms of the Creative Commons Attribution Non-Commercial License, which permits unrestricted non-commercial use, distribution, and reproduction in any medium, provided the original work is properly cited.

\begin{abstract}
Background: Premature rupture of membranes at term (PROM) is defined as a spontaneous rupture of membranes after 37 completed weeks of gestation and before the onset of regular painful uterine contractions. PROM occurs in 5$10 \%$ of all pregnancies of which approximately $80 \%$ occur at term. The study aimed to compare the maternal and neonatal outcome in patients with term PROM receiving active induction versus expectant management.

Methods: The present study was a prospective randomised controlled trial, conducted on 100 term antenatal women with PROM in the Department of Obstetrics and Gynaecology, UPUMS, Saifai from January 2016 to June 2017. 50 antenatal women received immediate induction with oral misoprostol while another 50 antenatal women were expectantly managed for 24 hours. The latency period, PROM delivery interval, maternal and neonatal outcome were compared and subjected to statistical analysis.

Results: $42 \%$ of active management group and 30\% of expectant management group had a latency period of 12-20 hours and results were found to be statistically significant ( $\mathrm{p}$ value $=0.005$ ). There was no statistically significant difference in the rate of caesarean section, maternal and neonatal morbidity in both the groups.

Conclusions: Immediate labour induction in patients with term PROM resulted in significant shortening of latent period and PROM to delivery interval without any increase in caesarean section rate as compared to expectant management group.
\end{abstract}

Keywords: Labour induction, Latent period, PROM

\section{INTRODUCTION}

Premature rupture of membranes at term (PROM) is defined as a spontaneous rupture of membranes after 37 completed weeks of gestation and before the onset of regular painful uterine contractions. ${ }^{1}$ PROM occurs in 5$10 \%$ of all pregnancies of which approximately $80 \%$ occur at term. ${ }^{2}$ The aetiology of PROM is multifactorial. ${ }^{2}$ At term, PROM can be physiological variation rather than a pathological event. PROM occurs when intrauterine pressure overcomes membrane resistance.
This happens due to weakening of membranes either congenital or acquired (smoking and vitamin $\mathrm{C}$ deficiency), or because of damaging factors either mechanical during amniocentesis or damage by infection (Trichomonas infection, group B streptococci, bacterial vaginosis). Failure of mechanical support such as cervical dilatation can lead to premature rupture of membrane. ${ }^{3}$ Other etiological factors are overdistended uterus, big baby, polyhydramnios and multiple pregnancy. ${ }^{4}$ Premature rupture of membranes is associated with several complications of pregnancy (i.e. pregnancy 
induced hypertension, uterine blunt trauma and uterine malformations). Several external factors are thought to cause premature rupture of membranes (i.e. drop in barometric pressure, and sexual intercourse).$^{5}$

Some researchers suggest that the evidence of infection within 12 hours of premature rupture of membranes indicates an antecedent infection, whereas evidence of infection after 72 hours indicates infection resulting from premature rupture of membranes. The majority of women at term presenting with premature rupture of membranes will go into labour spontaneously by the 48 to 72 hours.

Some obstetricians believe that waiting for labour to begin spontaneously is preferable for mothers if there is no evidence of foetal or maternal compromise, since the risk of caesarean section may be lowe. ${ }^{6}$ The present study is being planned to compare the efficacy of active management and expectant management in patient of PROM at term on their fetomaternal and perinatal outcome.

\section{METHODS}

The present study was a prospective randomised controlled trial, conducted on 100 term antenatal women in the Department of Obstetrics and Gynaecology, UPUMS, Saifai from January 2016 to June 2017.

All antenatal women with confirm diagnosis of PROM at term attending Outpatient Department (OPD) of UPUMS, Saifai were enrolled for the study. Diagnosis of PROM were based on

- Clinical history of passage of liquor

- Palpation through cervical canal

- Pooling of fluid in posterior fornices seen by speculum examination

- Reduced liquor volume on sonography (AFI) in selected women where clinical finding were inconclusive.

\section{Inclusion criteria}

- $\quad$ Pregnancy $\geq 37$ weeks of gestation confirmed by LMP or by early sonography with diagnosis of PROM

- $\quad$ Single foetus in vertex presentation

- Absence of active labour or features suggestive of foetal distress including meconium stained liquor

- No contraindication for vaginal delivery

- No known hypersensitivity to prostaglandin

- No intervention outside the hospital.

\section{Exclusion criteria}

- $\quad$ PROM before 37 completed weeks
- Foetal distress or meconium stained amniotic fluid at admission

- Patient with features of chorioamnionitis like fever, tachycardia, uterine tenderness and/or foul-smelling liquor

- Previous caesarean section or major uterine surgery

- Medical condition like heart disease, asthma, glaucoma, PET, DM, Rh incompatiblity, twins

- IUGR, foetal anomalies and polyhydramnions.

Each antenatal woman included in the study were subjected to complete history taking (personal, obstetric and gynaecological); general examination, abdominal examination and vaginal examination Routine investigations including urine culture sensitivity and high vaginal swab culture sensitivity were done. Admission test and ultrasonography was also done. All pregnant women received broad spectrum antibiotics. Informed consent for inclusion criteria in the study was taken after proper counselling.

These patients were randomly divided into 2 groups:

\section{Group 1 (active management)}

Half of the patients where labour was induced within 6 hours after rupture of membranes.

Induction was done with 50 microgram oral misoprostol 4 hourly. Subsequently depending on the partogram, labour was augmented with intravenous oxytocin. The dose of misoprostol was repeated after 4 hours if uterine contraction was $<2$ in 10 minutes. If active labour was not established after 4 dose of oral misoprostol, an I/V infusion of injection oxytocin dose of $1 \mathrm{ml}$ (5IU) in $500 \mathrm{ml}$ Ringer Lactate or Dextrose 5\% was started after at least 4 hours of last dose of misoprostol, at the rate of 15-20 drops $(10 \mathrm{Mu})$ per minutes as starting dose, which was increased by 10 drops (5Mu) every 20-30 minutes as needed till uterine contraction rate of 3 contractions every 10 minutes for 2 consecutive 10 minutes period was achieved.

\section{Group 2 (expectant management)}

50 patients who were allowed to go into spontaneous labour for 24 hours.

If patient failed to go into labour within 24 hours, reassessment of cervical finding was done, and labour was induced with $50 \mathrm{mcg}$. Oral misoprostol following same protocol as in Group 1.

Partographic monitoring of labour was done in all women. Onset of labour was determined by either regular uterine contraction or progressive cervical dilatation. Active labour was determined by 3 or more uterine contractions in 10 minutes or $4 \mathrm{~cm}$ of cervical dilatation. 
Any adverse effect (tachysystole, hyperstimulation syndrome, hypertonus) was recorded.

The main maternal outcomes included latency period (duration from rupture of membrane to the onset of labour pain); interval period (duration from rupture of membrane to delivery); vaginal delivery rates; operative delivery rates, maternal morbidity and mortality (postpartum haemorrhage, vaginal and cervical tears and chorioamnionitis). The foetal outcomes included serious neonatal morbidity and perinatal deaths with special concern to neonatal infection, neonatal jaundice, 5 minutes APGAR score $<7$ and NICU admission rates. Data was collected and subjected to statistical analysis.

\section{RESULTS}

Table 1 shows the demographic profile of 100 antenatal women. Majority of women in both the groups belonged to 20-25 years. The mean geatational age in active and expectant group was $38.64 \pm 0.94$ weeks and $38.48 \pm 0.97$ weeks. Majority of the patients were primigravida, belonged to rural area and were unbooked in both groups.

Table 1: Demographic profile of patients.

\begin{tabular}{|c|c|c|c|c|}
\hline $\begin{array}{l}\text { Demographic } \\
\text { parameter }\end{array}$ & & Active management & $\begin{array}{l}\text { Expectant } \\
\text { management }\end{array}$ & P value \\
\hline \multirow{5}{*}{ Age (years) } & $<20$ & 12 & 13 & \multirow{5}{*}{0.12} \\
\hline & $20-25$ & 17 & 16 & \\
\hline & $25-30$ & 13 & 14 & \\
\hline & $30-35$ & 7 & 5 & \\
\hline & $>35$ & 1 & 2 & \\
\hline \multirow{4}{*}{ Gestational age (weeks) } & $37-38$ & 18 & 17 & \multirow{4}{*}{0.40} \\
\hline & $38-39$ & 24 & 26 & \\
\hline & $39-40$ & 6 & 6 & \\
\hline & $>40$ & 2 & 1 & \\
\hline \multirow{3}{*}{ Gravida } & 1 & 32 & 27 & \multirow{3}{*}{0.59} \\
\hline & 2 & 10 & 13 & \\
\hline & $3+$ & 8 & 10 & \\
\hline \multirow{4}{*}{ Parity } & 0 & 39 & 31 & \multirow{4}{*}{0.09} \\
\hline & 1 & 3 & 12 & \\
\hline & 2 & 3 & 3 & \\
\hline & $3+$ & 5 & 4 & \\
\hline \multirow{2}{*}{ Area } & Rural & 38 & 40 & \multirow{2}{*}{0.62} \\
\hline & Urban & 12 & 10 & \\
\hline \multirow{2}{*}{ Booking status } & Unbooked & 31 & 30 & \multirow{2}{*}{0.83} \\
\hline & Booked & 19 & 20 & \\
\hline
\end{tabular}

Table 2: Distribution of patients according to prom to admission interval.

\begin{tabular}{|c|c|c|c|}
\hline $\begin{array}{l}\text { Prom to } \\
\text { admission } \\
\text { interval } \\
\text { (hours) }\end{array}$ & $\begin{array}{l}\text { Active } \\
\text { management }\end{array}$ & $\begin{array}{l}\text { Expectant } \\
\text { management }\end{array}$ & $\begin{array}{l}P \\
\text { value }\end{array}$ \\
\hline$<2$ & 4 & 8 & \multirow{6}{*}{0.11} \\
\hline $2-4$ & 10 & 13 & \\
\hline $4-6$ & 17 & 15 & \\
\hline $6-8$ & 12 & 4 & \\
\hline $8-10$ & 3 & 8 & \\
\hline $10-12$ & 4 & 2 & \\
\hline
\end{tabular}

$34 \%$ of active management group and $30 \%$ of expectant management group were admitted in 4-6 hours (Table 2).

$42 \%$ of active management group and $30 \%$ of expectant management group had a latency period of 12-20 hours (Table 3) and results were found to be statistically significant $(\mathrm{p}$ value $=0.005) .40 \%$ of active management and $20 \%$ of expectant management were delivered within 6-12 hours and $46 \%$ of active management and $28 \%$ of expectant management group were delivered within 12-20 hours (Table 4) and results were highly significant $(\mathrm{p}$ value $=0.0001)$. Majority of the antenatal women $(70 \%$ in active management group 
and $54 \%$ in expectant management group) delivered vaginally (Table 5).

Table 3: Distribution of cases according to latency period.

\begin{tabular}{|llll|}
\hline $\begin{array}{l}\text { Latency } \\
\text { period } \\
\text { (hours) }\end{array}$ & $\begin{array}{l}\text { Active } \\
\text { management }\end{array}$ & $\begin{array}{l}\text { Expectant } \\
\text { management }\end{array}$ & $\begin{array}{l}\text { P } \\
\text { value }\end{array}$ \\
\hline$<6$ & 8 & 9 & \\
\hline $6-12$ & 17 & 8 & \multirow{2}{*}{0.005} \\
\hline $12-20$ & 21 & 15 & \\
\hline $20-24$ & 4 & 10 & \\
\hline$>24$ & 0 & 8 & \\
\hline
\end{tabular}

Table 4: Distribution of cases according to prom to delivery interval.

\begin{tabular}{|lll|l|}
\hline $\begin{array}{l}\text { Prom to } \\
\text { delivery } \\
\text { interval } \\
\text { (hours) }\end{array}$ & $\begin{array}{l}\text { Active } \\
\text { management }\end{array}$ & $\begin{array}{l}\text { Expectant } \\
\text { management }\end{array}$ & $\begin{array}{l}\text { P } \\
\text { value }\end{array}$ \\
\hline$<6$ & 7 & 5 & \\
\hline $6-12$ & 20 & 12 & \multirow{2}{*}{0.0001} \\
\hline $12-24$ & 23 & 14 & \\
\hline$>24$ & 0 & 17 & \\
\hline
\end{tabular}

Table 5: Comparison of mode of delivery.

\begin{tabular}{|c|c|c|c|c|c|}
\hline \multirow[t]{2}{*}{$\begin{array}{l}\text { Mode of } \\
\text { delivery }\end{array}$} & \multicolumn{2}{|c|}{$\begin{array}{l}\text { Active } \\
\text { management }\end{array}$} & \multicolumn{2}{|c|}{$\begin{array}{l}\text { Expectant } \\
\text { management }\end{array}$} & $\begin{array}{l}P \\
\text { value }\end{array}$ \\
\hline & No. & $\%$ & No. & $\%$ & \multirow{4}{*}{0.25} \\
\hline LSCS & 10 & 20 & 16 & 32 & \\
\hline $\begin{array}{l}\text { Instrumental } \\
\text { delivery }\end{array}$ & 5 & 10 & 7 & 14 & \\
\hline $\begin{array}{l}\text { Vaginal } \\
\text { delivery }\end{array}$ & 35 & 70 & 27 & 54 & \\
\hline
\end{tabular}

The most common indication of caesarean section was foetal distress in both groups (Table 6).

Table 6: Distribution of cases according to indications of caesarean section.

\begin{tabular}{|llll|}
\hline Indications & $\begin{array}{l}\text { Active } \\
\text { management }\end{array}$ & $\begin{array}{l}\text { Expectant } \\
\text { management }\end{array}$ & $\begin{array}{l}\text { P } \\
\text { value }\end{array}$ \\
\hline $\begin{array}{l}\text { Foetal } \\
\text { distress }\end{array}$ & 4 & 6 & \\
\hline $\begin{array}{l}\text { Prolonged } \\
2^{\text {nd }} \text { stage }\end{array}$ & 3 & 3 & \multirow{2}{*}{0.80} \\
$\begin{array}{l}\text { Cervical } \\
\text { dystocia }\end{array}$ & 0 & 2 & \\
$\begin{array}{l}\text { Non- } \\
\text { progress of } \\
\text { labour }\end{array}$ & 1 & 2 & \\
\hline $\begin{array}{l}\text { Failure of } \\
\text { induction }\end{array}$ & 2 & 3 & \\
\hline Total & 10 & 16 & \\
\hline
\end{tabular}

In active management group, $20 \%$ patients with PROM duration of $<6$ hours and 36\% patients with PROM duration 6-12 hours delivered by vaginally (Table 7).

Table 7: Co-relation of mode of delivery with duration of prom in active management group.

\begin{tabular}{|c|c|c|c|c|c|}
\hline $\begin{array}{l}\text { Mode of } \\
\text { delivery } \\
(\mathrm{n}=\mathbf{5 0})\end{array}$ & $<6$ hours & $\begin{array}{l}\text { 6-12 } \\
\text { hours }\end{array}$ & $\begin{array}{l}12-18 \\
\text { hours }\end{array}$ & $\begin{array}{l}\text { 18-24 } \\
\text { hours }\end{array}$ & $\begin{array}{l}\mathbf{P} \\
\text { value }\end{array}$ \\
\hline $\begin{array}{l}\text { Vaginal } \\
\text { delivery }\end{array}$ & 10 & 17 & 7 & 1 & \multirow{4}{*}{0.20} \\
\hline $\begin{array}{l}\text { Instrumental } \\
\text { delivery }\end{array}$ & 1 & 5 & 3 & 1 & \\
\hline LSCS & 0 & 1 & 3 & 1 & \\
\hline Total & 11 & 23 & 13 & 3 & \\
\hline
\end{tabular}

Table 8: Co-relation of mode of delivery with duration of prom in expectant management group.

\begin{tabular}{|c|c|c|c|c|c|c|}
\hline $\begin{array}{l}\text { Mode of } \\
\text { delivery } \\
(n=50)\end{array}$ & $\begin{array}{l}<6 \\
\text { hrs }\end{array}$ & $\begin{array}{l}6-12 \\
\text { hrs }\end{array}$ & $\begin{array}{l}\text { 12-18 } \\
\text { hrs }\end{array}$ & $\begin{array}{l}\text { 18-24 } \\
\text { hrs }\end{array}$ & $\begin{array}{l}>24 \\
\text { hrs }\end{array}$ & $\begin{array}{l}\mathrm{P} \\
\text { value }\end{array}$ \\
\hline $\begin{array}{l}\text { Vaginal } \\
\text { delivery }\end{array}$ & 0 & 2 & 6 & 16 & 3 & \multirow{4}{*}{0.22} \\
\hline $\begin{array}{l}\text { Instrumental } \\
\text { delivery }\end{array}$ & 0 & 2 & 6 & 5 & 3 & \\
\hline LSCS & 0 & 1 & 1 & 3 & 2 & \\
\hline Total & 0 & 5 & 13 & 24 & 8 & \\
\hline
\end{tabular}

Table 9: Distribution of cases according to neonatal outcome.

\begin{tabular}{|c|c|c|c|}
\hline $\begin{array}{l}\text { Neonatal } \\
\text { outcome }\end{array}$ & $\begin{array}{l}\text { Active } \\
\text { management }\end{array}$ & $\begin{array}{l}\text { Expectant } \\
\text { management }\end{array}$ & $\begin{array}{l}\mathbf{P} \\
\text { value }\end{array}$ \\
\hline \multicolumn{4}{|c|}{ Apgar score at 1 minute } \\
\hline$<7$ & 4 & 5 & \multirow[b]{2}{*}{0.72} \\
\hline$>7$ & 46 & 45 & \\
\hline \multicolumn{4}{|c|}{ Apgar score at 5 minutes } \\
\hline$<7$ & 3 & 3 & \multirow{3}{*}{1.00} \\
\hline$>7$ & 47 & 47 & \\
\hline \multicolumn{3}{|l|}{ Birth weight } & \\
\hline$<2.5 \mathrm{~kg}$ & 10 & 11 & \multirow{7}{*}{0.75} \\
\hline $2.6-3.5 \mathrm{~kg}$ & 35 & 36 & \\
\hline$>3.6 \mathrm{~kg}$ & 5 & 3 & \\
\hline $\begin{array}{l}\text { NICU } \\
\text { admission }\end{array}$ & 4 & 5 & \\
\hline Still birth & 0 & 0 & \\
\hline Neonatal death & 0 & 0 & \\
\hline Healthy babies & 46 & 45 & \\
\hline \multicolumn{3}{|c|}{ Neonatal morbidity } & \multirow{6}{*}{0.67} \\
\hline Neonatal sepsis & 0 & 2 & \\
\hline $\begin{array}{l}\text { Neonatal } \\
\text { jaundice }\end{array}$ & 1 & 1 & \\
\hline RDS & 1 & 1 & \\
\hline Birth asphyxia & 2 & 1 & \\
\hline None & 46 & 45 & \\
\hline
\end{tabular}


In expectant management group, $24 \%$ patients with PROM duration of 18-24 hours and $6 \%$ patients with PROM duration of $>24$ hours delivered vaginally (Table 8).

Table 9 shows the neonatal outcome in both the groups. Apgar score was $>7$ in $92 \%$ at 1 minute and in $94 \%$ at 5 minutes in expectant management group. In expectant management group, Apgar score was $>7$ in $90 \%$ at 1 minute and in $94 \%$ at 5 minutes.majority of the neonates had birth weight between $2.6-3.5 \mathrm{~kg}$ in both groups.

Table 10: Distribution of cases according to maternal morbidity.

\begin{tabular}{|c|c|c|c|}
\hline $\begin{array}{l}\text { Maternal } \\
\text { morbidity }\end{array}$ & $\begin{array}{l}\text { Active } \\
\text { management }\end{array}$ & $\begin{array}{l}\text { Expectant } \\
\text { management }\end{array}$ & $\begin{array}{l}P \\
\text { value }\end{array}$ \\
\hline $\begin{array}{l}\text { Nausea, vomiting, } \\
\text { diarrhoea }\end{array}$ & 5 & 0 & \multirow{6}{*}{0.03} \\
\hline Chorioamnionitis & 0 & 2 & \\
\hline Puerperal pyrexia & 1 & 5 & \\
\hline Puerperal sepsis & 0 & 1 & \\
\hline None & 44 & 42 & \\
\hline Total & 50 & 50 & \\
\hline
\end{tabular}

NICU admission was required in 4 babies of active management group and 5 babies of expectant management group.There were no still births or neonatal deaths in both groups. In active management group, 10\% patients had side effects of misoprostol i.e nausea, vomitting and diarrhoea whereas in expectant management group, $4 \%, 10 \%$ and $2 \%$ patients had chorioamnionitis, puerperal pyrexia and puerperal sepsis respectively ( Table 10).

\section{DISCUSSION}

The mean age in active management group was $24.00 \pm 2.77$ years and in expectant management group was $24.96 \pm 3.44$ years. This was comparable to the study done by Mahmoud $\mathrm{F}$ et al and Mukharya $\mathrm{J}$ et al. ${ }^{6,7} 64 \%$ patients in active management group and 54\% patients of expectant management group were primigravida. This was comparable to the study done by Butt et al and Kunt et al. ${ }^{8,9}$ In the present study, $78 \%$ patients of active management group and $62 \%$ patients of expectant management group were nulliparous which is similar to the study done by Mukharya $\mathrm{J}$ et al. $^{7}$ Majority of the patients of both groups belonged to rural area and were unbooked. Similar study was done by Vaishnav J et al. ${ }^{10}$ In the present study, 34\% patients of active management group and $30 \%$ patients of expectant management group were admitted in 4-6 hours whereas $38 \%$ patients of active management group and $28 \%$ patients of expectant management group were admitted within 6-12 hours.

Similar results were reported by Mukharya $\mathbf{J}$ et al and Gracakrupa et al. ${ }^{7,11}$ No significant difference were found in present and past studies between PROM to admission interval.
About 99.9\% patients of active management group and $84 \%$ patients of expectant management group had latency period (time interval between PROM to active labour) within 24 hours. In the present study, significant difference $(\mathrm{P}=0.005)$ was found as regards to latency period in both groups. The latent period was shorter in the immediate induction group than the expectant group. the mean duration in immediate induction group was $8.9 \pm 5.5$ hours while in the expectant group was 16.1 \pm 9.9 hours. The results were comparable to the study done by Shetty et al and Crane et al. ${ }^{12,13}$ In the present study, $46 \%$ patients of active management group and $25 \%$ of expectant management group had PROM to delivery interval period within 20 hours whereas no patient of active management group and $34 \%$ patients in expectant management group had PROM to delivery interval more than 20 hours. PROM to delivery interval was significantly more in expectant management group. This study was supported by Mukharya $\mathrm{J}$ et al where $46 \%$ patients in active management group and $20 \%$ patients of expectant management group had PROM to delivery interval of 10.1-15 hours.

Rate of caesarean section and instrumental delivery was high in expectant management group compared to active management group but statistically no significant difference was found $(p=0.25)$. This study was similar to the study done by Chaudhari S et al, Shah $\mathrm{K}$ et al and Gracakrupa et al. ${ }^{14,15,11}$ In Mukharya $\mathrm{J}$ et al study, percentage of spontaneous vaginal delivery was $63 \%$ in active management group and $71 \%$ in expectant management group. ${ }^{7} 20 \%$ patients of active management group and $32 \%$ patients of expectant management groups underwent caesarean section. most common indication of caesarean section was meconium stained liquor/non reassuring foetal heart rate.There was no significant difference in the present study regarding indication of LSCS. Similar study was done by Shah K et al. ${ }^{15}$

About 92\% neonates of active management group and $90 \%$ patients of expectant management group had $>7$ Apgar score at 1 minute. 94\% neonates had $>7$ apgar score at 5 minutes in both groups. Similar study was done by Mahmoud F et al. ${ }^{6}$ NICU admission was seen in $8 \%$ neonates of active management group and 10\% neonates of expectant management group. There was no still birth and neonatal death in both groups. This is comparable to the study done by Chaudhari S et al, Vaishnav et al and Mukharya J et al. ${ }^{14,10,7}$

\section{CONCLUSION}

Immediate labour induction in patients with term PROM resulted in significant shortening of latent period and PROM to delivery interval without any increase in caesarean section rate as compared to expectant management group. There was no statistically significant differences in the rate of maternal and neonatal morbidity among both the groups. 


\section{ACKNOWLEDGMENTS}

Authors express their heartfelt gratitude to their colleagues and to their PG students of Obstetrics and Gynaecology Department for collecting data and undoubtedly to the ante natal patients without whom this work could not have been possible.

Funding: No funding sources

Conflict of interest: None declared

Ethical approval: The study was approved by the Institutional Ethics Committee

\section{REFERENCES}

1. Mead PB. Management of the patient with premature rupture of the membranes. Clinics Perinatol. 1980;7:243-55.

2. Parry S, Strauss JF. Mechanism of disease: premature rupture of the fetal membranes. $\mathrm{N}$ Engl $\mathrm{J}$ Med. 1998;338:663-70.

3. Larranaga-Azcarate C, Campo-Molina G, PerezRodriguez AF. Dinoprostone vaginal slow release system compared to expectant management in the active treatment of PROM at term: impact on maternal and foetal outcome. Actaobstetrica. 2008;87:195-200.

4. James R, Philip SJ, Disuia CB, Hammond WN. Etiology of premature rupture of membranes. In: James R, Scott Philip J, Disuia CB, Hammond WN (editors) Danforth's Obstetrics and Gynaecology. $8^{\text {th }}$ ed. New York: Lippncott Williams and Wilkins; 2000:269-70.

5. Ozden S, Delikara MN, Avci A. Intravaginal misoprostol vs expectant management in PROM with low Bishop scores at term. Int $\mathbf{J}$ obstet. 2002;77:109-15.

6. Midan MF. Early versus delayed induction following prelabour rupture of memebranes at term. AAMJ. 2012;10(2):367-81.

7. Mukharya J, Mukharya S. Comparative study of fetal and maternal outcomes of prelabour rupture of membranes at term. Int $\mathbf{J}$ Reprod Obstet Gynecol. 2017;6(1):149-163.

8. Butt KD, Bennett KA, Young DC. Randomized comparison of oral misoprostol and oxytocin for labour induction in term prelabour rupture of the menbranes. Obstet Gynecol. 1999;94(6):994-9.

9. Kunt C, Pektas M, Cakir A. Randomized trial of vaginal prostaglandin E2 versus oxytocin for labour induction in term premature rupture of the membrane. Taiwan J Obstet Gynecol. 2010;49(1):579.

10. Vaishnav J, Vaishnav G. A study of feto-maternal outcome in patients with pre-labour rupturevof membranes at term (>37 weeks). Med Sci. 2011;1(2):118-24.

11. Gracekrupa F, Cecatti JG, de Castro Surita FG. Misoprostol versus expectant management in premature rupture of membranes at term. BJOG. 2005;112:1284-90.

12. Shetty A, Stewart K, Stewart G. Active management of term prelabour rupture of the membranes at term with oral misoprostol. $\mathrm{Br} \mathrm{J}$ Obstet Gynecol. 2002;109(6):645-50.

13. Crane J, Delany T and Hutchens D. Oral misoprostol for premature rupture of membranes at term. Am J Obstet Gynecol. 2003;189(3):720-4.

14. Chaudhari S, Kumar BP, Bhattacharyya S, Nath M. Premature rupture of membrane at term: immediate induction with PGE2 gel compared with delayed induction with oxytocin. J Obstet Gynecol India. 2006;56(3):224-9.

15. Krupa S, Haresh D. Premature rupture of membrane at term: early induction versus expectant management. J Obstet Gynecol. 2012;62(2):172-5.

Cite this article as: Rawat R, Divedi P, Debbarma $S$, Vishwakarma S, Mittal N. A comparative study between active and expectant management of premature rupture of membranes at term on fetomaternal and perinatal outcome in rural population. Int J Reprod Contracept Obstet Gynecol 2018;7:2393-8. 